\title{
We must disclose
}

We must

disclose

So now we must disclose the ratio -

Political a thing this surely be -

Of worker pay to that of CEO.

We mustn't let the average worker see

How much her pay is trailing that of those

Who sit atop this global company!

What can we do to make the number close

To our competitors'? The rule's not tight,

But there's a lot we'd rather not disclose

About our median employee's plight.

What sampling techniques can we use? It's worth

The effort spent in getting this just right.

How might we move the middle paycheck north

Without (of course!) reducing pay for us?

Some paltry-paying jobs - let's send them forth

To other lands or firms where they won't fuss

About a part-time job with tiny pay.

Removing low-paid jobs creates bias

That helps us say what we would like to say.

Though not intended by Dodd-Frank at all,

What's measured, not what's wanted, rules the day.

Like so we'll answer Congress at its call,

And show we're not so greedy after all.

\author{
Matthew Christian Mastilak \\ Xavier University, Cincinnati, Ohio, USA
}

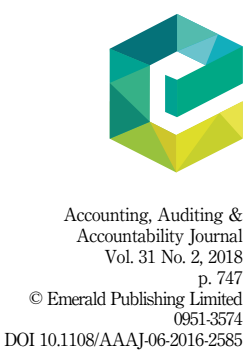

